\title{
SISTEM BANTU UNTUK PENGRAJIN DALAM MENENTUKAN KAYU TERBAIK UNTUK BAHAN GITAR DENGAN MENGGUNAKAN METODE MOORA
}

\author{
Tundo*1, Wisnu Dwi Nugroho ${ }^{2}$ \\ ${ }^{1}$ Universitas Putra Bangsa, Kebumen, ${ }^{2}$ Universitas Teknologi Yogyakarta, Yogyakarta \\ Email: 1asna8mujahid@gmail.com, ${ }^{2}$ d.wisnu91@yahoo.co.id \\ *Penulis Korespondensi
}

(Naskah masuk: 16 Juli 2020 , diterima untuk diterbitkan: 15 November 2021)

\begin{abstract}
Abstrak
Penelitian ini bertujuan untuk membantu pengrajin kayu di Dongkelan, Krapyak, Yogyakarta dalam menentukan kayu terbaik untuk dijadikan sebagai bahan gitar, karena sering terjadi keluhan dari para pembeli bahwa bahan yang dijadikan bahan gitar cepat lapuk dan kusam dari segi warnah. Berdasarkan permasalahan tersebut, dicari suatu solusi dengan menggunakan metode Decision Support System Multi Objective Optimization on the basic of Ratio Analysis (MOORA) serta dibantu oleh pakar dalam menentukan kriteria yang tepat berkaitan penentuan kayu terbaik yang digunakan dalam pembuatan bahan gitar, setelah berdiskusi panjang ditemukan hasil kriteria yang tepat berdasarkan permasalahan, berupa kriteria kekuatan kayu, serat kayu, tekstur, dan berat kayu. Semua kriteria tersebut, kemudian diproses dengan menggunakan metode MOORA, dengan data yang digunakan sebanyak 29 jenis data kayu, yang diperoleh dari pengrajin yang ada di wilayah tersebut. Setelah diproses, diperoleh hasil 3 kayu terbaik yang layak untuk digunakan sebagai bahan pembuatan gitar secara berurutan dalah kayu Bubinga dengan nilai 18,36785, kayu Bocote dengan nilai 17,33385, dan kayu Eboni dengan nilai 17,33385 dari beberapa pilihan alternatif kayu yang ada. Membuktikan hasil dari metode MOORA, maka dilakukan responden secara langsung dengan memberikan hasil metode kepada pakar pembuat gitar. Dari 15 pakar pembuat gitar, 13 mengatakan setuju dengan peringkat 3 terbesar, dan 2 mengatakan kurang setuju. Sehingga ditemukan tingkat akurasi berdasarkan penilaian pakar sebesar $86,67 \%$
\end{abstract}

Kata kunci: Pembuatan Bahan Gitar, Kayu Terbaik, Decision Support System, MOORA.

\section{HELP SYSTEM FOR CRAFTSMEN IN DETERMINING THE BEST WOOD FOR GUITAR MATERIALS USING MOORA METHOD}

\begin{abstract}
This study aims to assist wood craftsmen in Dongkelan, Krapyak, Yogyakarta in determining the best wood to be used as guitar material, because there are frequent complaints from buyers that the material used for guitar is rotten quickly and is dull in terms of color. Based on these problems, a solution was sought using the Multi Objective Optimization on the basic of Ratio Analysis (MOORA) Decision Support System method and assisted by experts in determining the right criteria related to determining the best wood used in making guitar materials, after a long discussion found the results. the right criteria based on the problem, in the form of wood strength criteria, wood grain, texture, and wood weight. All of these criteria are then processed using the MOORA method, with the data used as much as 29 types of wood data, which are obtained from craftsmen in the area. After processing, the 3 best woods that are suitable for use as a guitar-making material are Bubinga wood with a value of 18.36785, Bocote wood with a value of 17.333385, and Eboni wood with a value of 17.333385 from several alternative wood choices. . Proving the results of the MOORA method, the respondents directly gave the results of the method to guitar-making experts. Of the 15 expert guitar makers, 13 said they agreed with the third largest ranking, and 2 said they disagreed. So that it found the level of accuracy based on expert judgment of 86.67\%.
\end{abstract}

Keywords: Guitar Material Making, The Best Wood, Decision Support System, MOORA.

\section{PENDAHULUAN}

Gitar merupakan suatu alat musik yang berbahan kayu dengan dilengkapi senar-senar yang dipetik dengan menggunakan jari atau pick gitar (Kautsar,
2016). Ketika dipetik, senar-senar pada gitar ini akan menghasilkan bunyi. Menurut jenisnya gitar dapat dibedakan menjadi dua yaitu gitar elektrik dan gitar akustik.Gitar elektrik menggabungkan komponennya dengan mic listrik atau pick up (spul), sedangkan gitar 
akustik menggunakan sadel atau jembatan tempat pengikat senar untuk mengalirkan suara ke kedalam ruang suara (Zian Fahri, 2014). Terdapat banyak jenis kayu yang digunakan untuk membangun gitar diantaranya eboni, sonokeling, meranti, merbau, dan lain-lain. Hal ini membuat para pembuat gitar kesulitan untuk menentukan jenis kayu yang tepat digunakan sebagai bahan pembuatan gitar. Dalam mengatasi kesulitan pemilihan kayu ini maka diperlukan suatu penelitian yang tepat dalam menggunakan kayu yang terbaik untuk digunakan dalam pembuatan bahan gitar, dengan informasi menurut ahlinya, yang kemudian akan diimplementasikan ke dalam bentuk aplikasi (Olivianita and Ekojono, 2016). Sistem bantu ini adalah bagian dari sistem informasi yang dipergunakan untuk mengambil keputusan ketika menghadapi sebuah kasus atau masalah (Ramadani, Sihombing and Parlina, 2019), dalam mendukung pengambilan keputusan, sistem bantu akan menghitung kriteria dengan menggunakan sistem komputer untuk mengolah informasi yang diperlukan dalam pengambilan keputusan. Pengembangan metode dalam sistem bantu dari yang paling sederhana ke arah yang lebih spesifik seperti Weighted Sum Model, Analytical Hierarchy Process, dan lain-lainya.

Pada penelitian ini penulis menerapkan metode Multi Objective Optimization on the basic of Ratio Analysis (MOORA) dalam menentukan kayu terbaik untuk digunakan sebagai bahan gitar dengan kriteria kekuatan kayu, serat kayu, tekstur, dan berat kayu. Digunakannya metode MOORA karena sebuah kerangka untuk mengambil keputusan dengan efektif atas persoalan yang kompleks dengan menyederhanakan dan mempercepat proses pengambil keputusan dengan memecahkan persoalan tersebut kedalam bagian-bagiannya (Cahyani, Arif and Ningsih, 2019), serta mensintesis mana yang memiliki prioritas paling tinggi dan bertindak untuk mempengaruhi hasil pada situasi tersebut. Beberapa penelitian yang serupa yang penulis ambil sebagai bahan dalam pembuatan penelitian ini. Pertama menurut (Nugraha, 2016), dengan objek pemilihan kayu untuk gitar dengan menggunakan metode TOPSIS. Data Alternatif yang ada yaitu, kayu Alder, Mahogani, Baswood, dan Oak yang sekiranya tepat untuk dipilih menjadi gitar dengan dipengaruhi oleh kriteria serat kayu, tekstur, berat, dan kenyamanan. Dari hasil yang diperoleh bahwa kayu Alder mempunyai nilai yang paling tinggi, maka kayu Alder adalah alternatif yang layak untuk dipilih menjadi kayu terbaik dalam pembuatan gitar. Kedua menurut (Simanjuntak et al., 2018), dengan objek penentuan kayu terbaik untuk bahan gitar dengan menggunakan metode WASPAS. Data Alternatif yang ada yaitu, kayu Rosewood, Maple, Poplar, Mahogani, Basswod, Alder, dan Ash yang sekiranya tepat untuk dipilih menjadi gitar dengan dipengaruhi oleh kriteria jenis kayu, serat kayu, tekstur, dan berat. Dari hasil yang diperoleh bahwa kayu Ash mempunyai nilai yang paling tinggi yaitu 5,067, maka kayu Ash adalah alternatif yang layak untuk dipilih menjadi kayu terbaik dalam pembuatan gitar.

Ketiga menurut (Prasetyaningrum et al., 2020), dengan objek pemilihan kayu untuk pembuatan gitar dengan menggunakan SAW. Data Alternatif yang ada yaitu, kayu bear claw, german spruce, indian rosewood, curly maple, dan 12 kayu lainnya, yang sekiranya tepat untuk dipilih menjadi gitar dengan dipengaruhi oleh kriteria karakter suara, umur, fisik, dan pola. Dari hasil yang diperoleh bahwa kayu Rziricote mempunyai nilai yang paling tinggi yaitu 13, maka kayu Rziricote adalah alternatif yang layak untuk dipilih menjadi kayu terbaik dalam pembuatan gitar.

Berdasarkan hal-hal yang telah dijelaskan di atas, pemodelan penelitian ini dilakukan dengan tujuan untuk membantu pengrajin kayu di Dongkelan, Krapyak, Yogyakarta dalam menentukan kayu yang terbaik untuk dijadikan sebagai bahan pembuatan gitar dengan bantuan pakar ahli, dimana data yang diperoleh adalah kumpulan data kayu yang digunakan oleh pengrajin di Dongkelan, Krapyak, Yogyakarta untuk berbagai aneka pembuatan, diantaranya mebel dan furniture. Kelebihan dari metode MOORA memiliki tingkat selektivitas yang baik karena dapat menentukan tujuan dari kriteria yang saling bertentangan, serta penelitian ini mengedepankan permasalahan yang ada di Dongkelan, Krapyak, Yogyakarta dengan menggunakan data kayu yang ada disana bukan berdasarkan penelitian yang pernah dilakukan sebelumnya.

\section{METODE PENELITIAN}

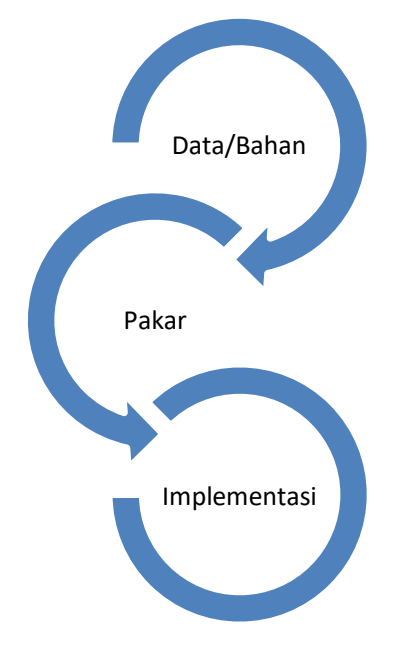

Gambar 1. Alur Penelitian

A. Data/Bahan

Data yang diperoleh berupa kayu yang akan digunakan untuk membuat bahan gitar. Kayu yang ada di instansi tampak seperti Tabel 1. Data Kayu. 


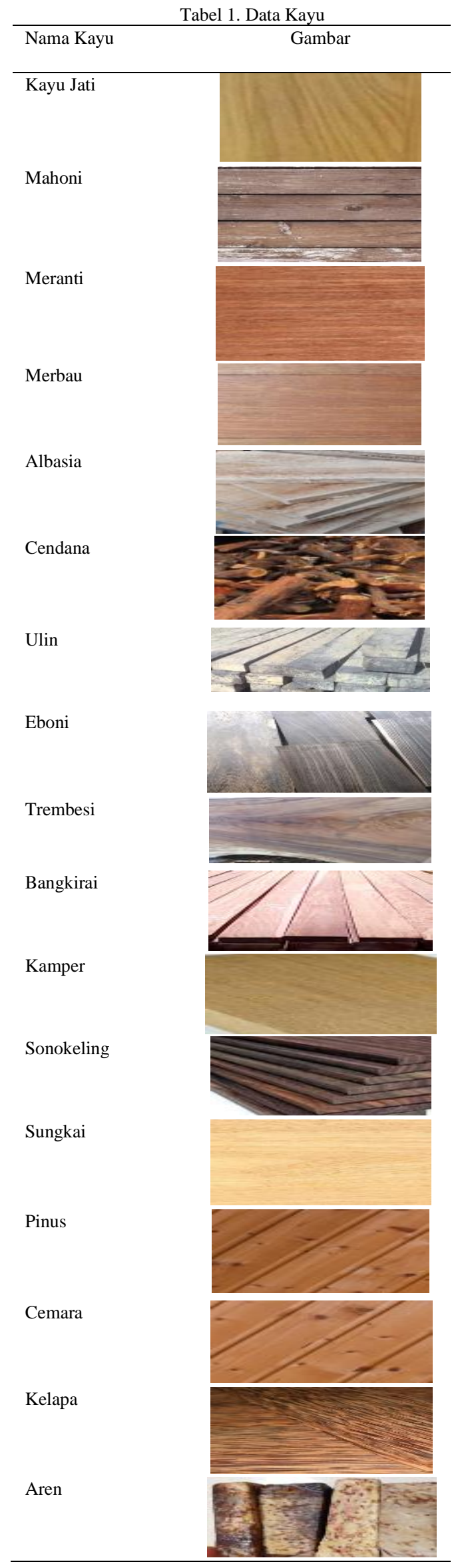

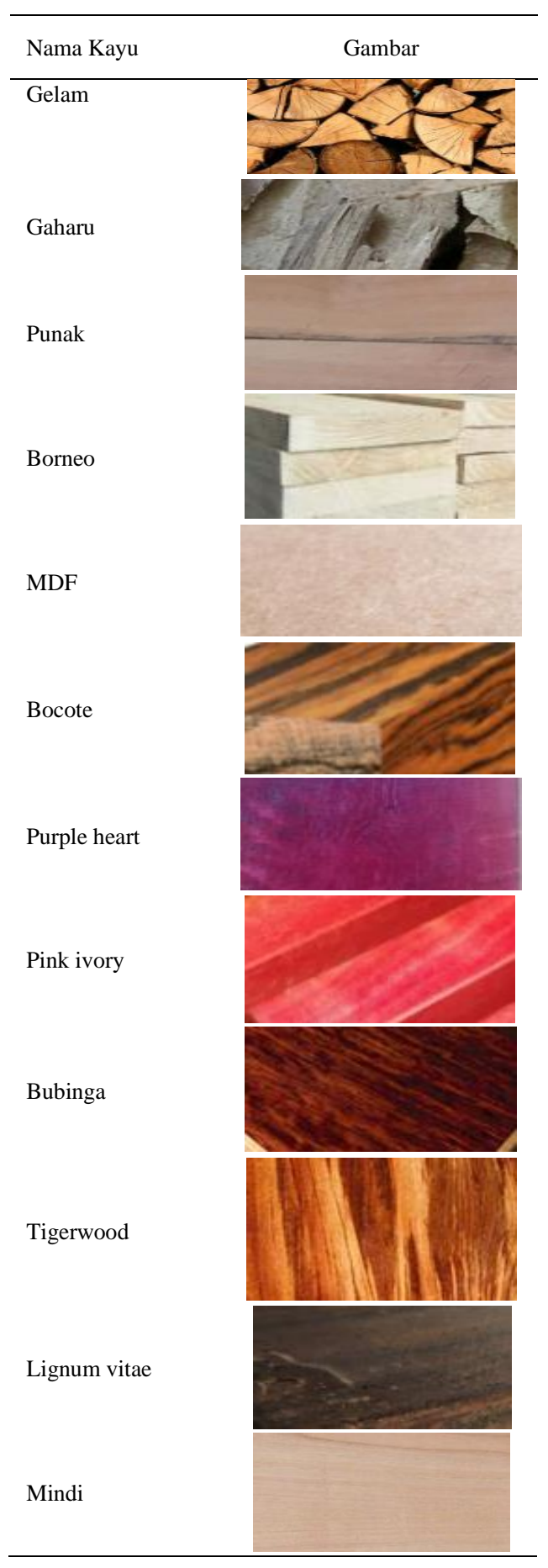

B. Pakar

Pakar disini membantu penulis dalam menentukan kriteria yang umum digunakan dalam membuat bahan gitar, serta menentukan himpunan dari setiap kriteria, beserta nilainya, dengan mengacu kepada permasalahan instansi yang bersangkutan, setelah itu disepakati bahwa kriteria yang digunakan untuk menentukan kayu terbaik dalam pembuatan bahan gitar, terdiri dari kekuatan kayu, serat kayu, tekstur, dan berat kayu.

C. Implementasi

Implementasi penerapan metode MOORA dalam menentukan kayu terbaik dalam pembuatan bahan 
gitar, menurut (Chakraborty and Zavadskas, 2014), MOORA adalah sistem multi obyektif yang memaksimalkan dua atau lebih atribut yang saling berlawanan secara bersamaan. Metode ini diyakini dapat memecahkan masalah dengan permasalahan matematika yang kompleks. Metode MOORA mempunyai tingkat fleksibilitas dan kemudahan untuk dimengerti dalam memilahkan bagian subjektif dari suatu proses penilaian ke dalam kriteria bobot keputusan dengan beberapa atribut pengambilan keputusan. Metode ini mempunyai tingkat selektif yang baik karena dapat menemukan tujuan dari kriteria yang berlawanan. Kriteria yang digunakan bisa bernilai menguntungkan (benefit) atau yang tidak menguntungkan (cost). Kelebihan metode MOORA yaitu lebih sederhana, relatif stabil, dan kuat, bahkan metode ini tidak memperlukan seorang ahli dibidang matematika untuk menggunakannya serta membutuhkan perhitungan matematika yang sederhana.

Berikut tahapan implementasi sistem yang dibangun menggunakan metode MOORA dalam menentukan kayu terbaik dalam pembuatan bahan gitar, seperti pada Gambar 2. Alur Sistem.

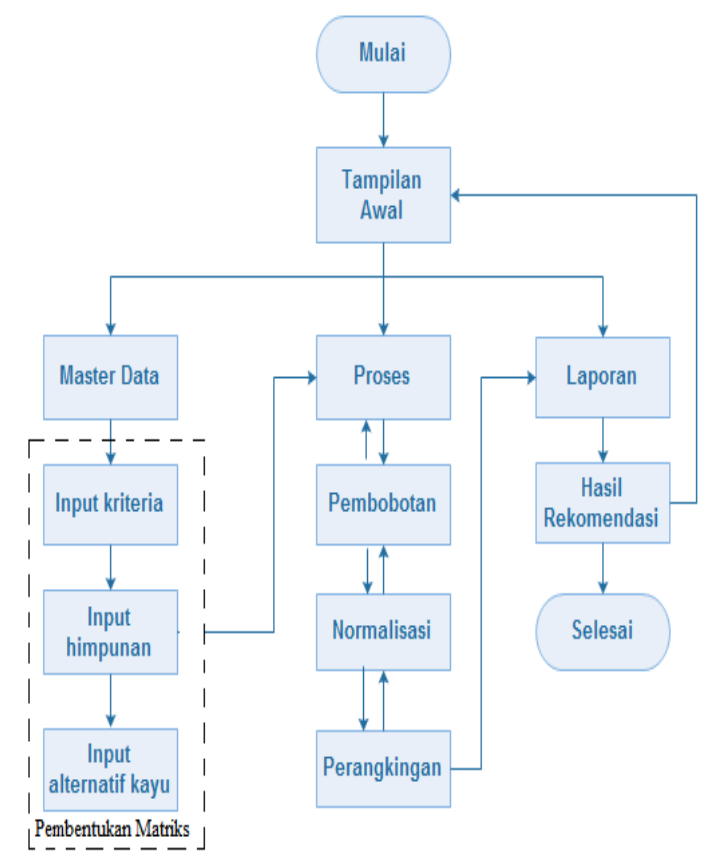

Gambar 2. Alur Sistem

\subsection{Kriteria dan Bobot}

Tabel kriteria dan bobot merupakan tabel yang berisi data kriteria yang digunakan dalam proses perhitungan, data kriteria berisi kode, nama kriteria, atribut, dan bobot dari setiap kriteria (Simanjuntak et al., 2018). Berikut Tabel 2. Kriteria dan Bobot.

\begin{tabular}{llll}
\multicolumn{4}{c}{ Tabel 2. Kriteria dan Bobot } \\
\hline Kode & Nama Kriteria & Atribut & Bobot \\
Kriteria & & & \\
\hline C01 & Kekuatan Kayu & Benefit & 20 \\
C02 & Serat Kayu & Benefit & 35 \\
C03 & Tekstur & Benefit & 30 \\
\hline
\end{tabular}

\begin{tabular}{llll}
\hline $\begin{array}{l}\text { Kode } \\
\text { Kriteria }\end{array}$ & Nama Kriteria & Atribut & Bobot \\
\hline C04 & Berat Kayu & Cost & 15 \\
\hline
\end{tabular}

\subsection{Himpunan}

a. Himpunan Kriteria Kekuatan Kayu

Kriteria kekuatan kayu adalah kekuatan dari kayu tersebut terhadap daya tekan, yang dibagi menjadi 4 bagian himpunan yaitu, sangat kuat, kuat, sedang, dan mudah patah. Setiap himpunan memiliki nilai yang telah disetujui oleh pakar, yang terlihat pada Tabel 3. Himpunan Kriteria Kekuatan Kayu.

\begin{tabular}{lll}
\multicolumn{3}{c}{ Tabel 3. Himpunan Kriteria Kekuatan Kayu } \\
\hline Nomor & Nama Kriteria Kekuatan Kayu & Nilai \\
\hline 1 & Sangat Kuat & 5 \\
2 & Kuat & 4 \\
3 & Sedang & 3 \\
4 & Mudah Patah & 2 \\
\hline
\end{tabular}

b. Himpunan Kriteria Serat Kayu

Kriteria serat kayu adalah sifat serat dari kayu itu sendiri dinilai dari bentuk dan pola kayu, yang dibagi menjadi 4 bagian himpunan yaitu, sangat padat, padat, beruas lurus, dan berwarnah. Setiap himpunan memiliki nilai yang telah disetujui oleh pakar, yang terlihat pada Tabel 4. Himpunan Serat Kayu.

\begin{tabular}{clc}
\multicolumn{3}{c}{ Tabel 4. Himpunan Serat Kayu } \\
\hline Nomor & \multicolumn{1}{c}{ Nama Kriteria Serat Kayu } & Nilai \\
\hline 1 & Sangat Padat & 5 \\
2 & Padat & 4 \\
3 & Beruas Lurus & 3 \\
4 & Berwarnah & 2 \\
\hline
\end{tabular}

c. Himpunan Kriteria Tekstur

Kriteria tekstur adalah ukuran relatif sel kayu yang dapat dinilai ketika melihat secara langsung kayu tersebut, yang kemudian dipegang. Himpunan kriteria tekstur dibagi menjadi 4 bagian himpunan Tabel himpunan yaitu, sangat halus, halus, sedang, dan kasar. Setiap himpunan memiliki nilai yang telah disetujui oleh pakar, yang terlihat pada Tabel 5. Himpunan Kriteria Tekstur.

\begin{tabular}{lll}
\multicolumn{3}{c}{ Tabel 5. Himpunan Kriteria Tekstur } \\
\hline Nomor & \multicolumn{1}{c}{ Nama Kriteria Tekstur } & Nilai \\
\hline 1 & Sangat Halus & 5 \\
2 & Halus & 4 \\
3 & Sedang & 3 \\
4 & Kasar & 2 \\
\hline
\end{tabular}

d. Himpunan Kriteria Berat Kayu

Kriteria berat kayu adalah berat jenis dari kayu itu sendiri, yang dibagi menjadi 5 bagian yaitu, lebih besar dari $30 \mathrm{~kg}$ berat jenis kayu, diantara $25 \mathrm{~kg}-29 \mathrm{~kg}$ berat jenis kayu, $20 \mathrm{~kg}-24 \mathrm{~kg}$ berat jenis kayu, $15 \mathrm{~kg}-19 \mathrm{~kg}$ berat jenis kayu, 
dan kurang dari $14 \mathrm{~kg}$ berat jenis kayu. Setiap himpunan memiliki nilai yang telah disetujui oleh pakar, yang terlihat pada Tabel 6. Himpunan Kriteria Berat Kayu.

\begin{tabular}{lll}
\multicolumn{3}{c}{ Tabel 6. Himpunan Kriteria Berat Kayu } \\
\hline Nomor & \multicolumn{1}{c}{ Nama Kriteria Berat Kayu } & Nilai \\
\hline 1 & Lebih besar dari 30 kg & 5 \\
2 & $25 \mathrm{Kg}-29 \mathrm{~kg}$ & 4 \\
3 & $20 \mathrm{Kg}-24 \mathrm{~kg}$ & 3 \\
4 & $15 \mathrm{Kg}-19 \mathrm{~kg}$ & 2 \\
5 & Kurang dari $14 \mathrm{~kg}$ & 1 \\
\hline
\end{tabular}

\subsection{Alternatif}

Alternatif merupakan tabel yang berisi data alternatif yang digunakan dalam proses perhitungan ini. Tabel alternatif dapat dilihat pada Tabel 7 . Alternatif.

\begin{tabular}{ll}
\multicolumn{2}{c}{ Tabel 7. Alternatif } \\
\hline Kode Alternatif & Nama Kayu \\
\hline A0001 & Kayu Jati \\
A0002 & Mahoni \\
A0003 & Meranti \\
A0004 & Merbau \\
A0005 & Albasia \\
A0006 & Cendana \\
A0007 & Ulin \\
A0008 & Eboni \\
A0009 & Trembesi \\
A0010 & Bangkirai \\
A0011 & Kamper \\
A0012 & Sonokeling \\
A0013 & Sungkai \\
A0014 & Pinus \\
A0015 & Cemara \\
A0016 & Kelapa \\
A0017 & Aren \\
A0018 & Gelam \\
A0019 & Gaharu \\
A0020 & Punak \\
A0021 & Borneo \\
A0022 & MDF \\
A0023 & Bocote \\
A0024 & Purple heart \\
A0025 & Pink ivory \\
A0026 & Bubinga \\
\hline & \\
Tabel 7. Alternatif Lanjutan \\
\hline Kode Alternatif & Nama Kayu \\
\hline A0027 & Tigerwood \\
A0028 & Lignum vitae \\
A0029 & Mindi \\
\hline &
\end{tabular}

\subsection{Pembobotan}

Perubahan matrik data awal menjadi data pembobotan, maksudnya semua data awal diubah dalam bentuk nilai bobot sesuai dengan nilai dari himpunan kriteria (Maharani et al., 2018).

\subsection{Normalisasi}

Normalisasi memiliki tujuan untuk menggabungkan setiap elemen matriks sehingga elemen pada matriks mempunyai nilai yang sejenis. Setiap elemen matrik dibagi dengan akar kuadrat dari jumlah kuadrat dari setiap alternatif per kriteria/atribut (Rani et al., 2019). Rasio ini dapat dinyatakan:

$$
\mathrm{X}^{*} \mathrm{ij}=\frac{x i j}{\sqrt{\left[\sum_{j=1}^{m} x i j^{2}\right]}}
$$

Keterangan:

xij : Matriks alternatif $\mathrm{j}$ dengan kriteria $\mathrm{i}$ i : $1,2,3,4,5, \ldots, \mathrm{n}$ adalah urutan atribut kriteria $\mathrm{j}: 1,2,3,4,5, \ldots, \mathrm{m}$ adalah urutan alternatif $\mathrm{X}^{*} \mathrm{ij}$ : Matriks Normalisasi alternatif $\mathrm{j}$ dengan kriteria i

\subsection{Perangkingan}

Perangkingan dalam metode ini, yaitu dengan melakukan ketentuan pemberian bobot adalah nilai bobot jenis kriteria maksimum lebih besar dari nilai bobot jenis kriteria minimum (Nababan et al., 2018). Dalam menandakan bahwa sebuah atribut lebih penting bisa dikalikan dengan bobot yang sesuai (Manurung, 2018). Rumusnya adalah perkalian bobot kriteria terhadap nilai atribut maksimum dikurang perkalian bobot kriteria terhadap nilai atribut minimum, jika dirumuskan maka:

$$
\mathrm{Yi}=\sum_{i=1}^{g} w j X_{\mathrm{i}} j-\sum_{j=g+1}^{n} w j X_{\mathrm{i}} j
$$

Keterangan:

i : $1,2,3,4,5, \ldots, \mathrm{g}$ adalah atribut kriteria dengan status maksimum

$\mathrm{j}: \mathrm{g}+1, \mathrm{~g}+2, \mathrm{~g}+3, \mathrm{~g}+4, \mathrm{~g}+5, \ldots, \mathrm{n}$ adalah atribut

kriteria dengan status minimum

$\mathrm{Wj}$ : bobot terhadap alternatif $\mathrm{j}$

\subsection{Hasil Rekomendasi}

Hasil rekomendasi kayu terbaik dengan dihitung menggunakan metode MOORA, yang menempati peringkat pertama, maka kayu tersebut yang tepat digunakan untuk pembuatan bahan gitar.

\section{HASIL DAN PEMBAHASAN}

\subsection{Perhitungan Manual}

Langkah awal lakukan pembentukan matrik antara data alternatif dengan data kriteria, hasil pembentukan tersebut yaitu berupa data awal yang berisi nilai dari setiap alternatif dan kriteria. Data awal dapat dilihat pada Tabel 8. Data Awal.

\begin{tabular}{ccccc}
\multicolumn{5}{c}{ Tabel 8. Data Awal } \\
$\begin{array}{c}\text { Kode } \\
\text { Alternatif }\end{array}$ & $\begin{array}{c}\text { Kekuatan } \\
\text { Kayu }\end{array}$ & Serat Kayu & Tekstur & $\begin{array}{c}\text { Berat } \\
\text { Kayu/kg }\end{array}$ \\
\hline A0001 & Sangat Kuat & Sangat Padat & Sedang & 35
\end{tabular}


1182 Jurnal Teknologi Informasi dan Ilmu Komputer (JTIIK), Vol. 8, No. 6, Desember 2021, hlm. 1177-1186

\begin{tabular}{|c|c|c|c|c|}
\hline $\begin{array}{c}\text { Kode } \\
\text { Alternatif }\end{array}$ & $\begin{array}{c}\text { Kekuatan } \\
\text { Kayu }\end{array}$ & Serat Kayu & Tekstur & $\begin{array}{c}\text { Berat } \\
\text { Kayu/kg }\end{array}$ \\
\hline $\mathrm{A} 0002$ & Kuat & Sangat Padat & Kasar & 25 \\
\hline A0003 & Sedang & Padat & Halus & 30 \\
\hline A0004 & Sangat Kuat & Padat & Sedang & 30 \\
\hline A0005 & $\begin{array}{l}\text { Mudah } \\
\text { Patah }\end{array}$ & Beruas Lurus & Kasar & 24 \\
\hline A0006 & Sedang & Berwarnah & Sedang & 14 \\
\hline A0007 & Sangat Kuat & Padat & Halus & 36 \\
\hline A0008 & Kuat & Sangat Padat & $\begin{array}{l}\text { Sangat } \\
\text { Halus }\end{array}$ & 32 \\
\hline A0009 & Sedang & Padat & Halus & 28 \\
\hline A0010 & Sedang & Padat & Sedang & 20 \\
\hline A0011 & Kuat & Padat & Kasar & 25 \\
\hline A0012 & Kuat & Padat & Sedang & 29 \\
\hline A0013 & Sedang & Beruas Lurus & Sedang & 24 \\
\hline A0014 & $\begin{array}{l}\text { Mudah } \\
\text { Patah }\end{array}$ & Berwarnah & Sedang & 12 \\
\hline A0015 & $\begin{array}{l}\text { Mudah } \\
\text { Patah }\end{array}$ & Beruas Lurus & Sedang & 12 \\
\hline A0016 & $\begin{array}{l}\text { Mudah } \\
\text { Patah }\end{array}$ & Beruas Lurus & Kasar & 15 \\
\hline A0017 & $\begin{array}{l}\text { Mudah } \\
\text { Patah }\end{array}$ & Berwarnah & Kasar & 14 \\
\hline A0018 & Sedang & Berwarnah & Halus & 24 \\
\hline A0019 & Kuat & Berwarnah & Halus & 12 \\
\hline A0020 & Kuat & Padat & Sedang & 22 \\
\hline A0021 & Kuat & Padat & Sedang & 32 \\
\hline A0022 & Sedang & Beruas Lurus & Halus & 10 \\
\hline A 0023 & Kuat & Sangat Padat & $\begin{array}{c}\text { Sangat } \\
\text { Halus }\end{array}$ & 32 \\
\hline A 0024 & Sedang & Berwarnah & Halus & 30 \\
\hline \multicolumn{5}{|c|}{ Tabel 8. Data Awal Lanjutan } \\
\hline $\begin{array}{c}\text { Kode } \\
\text { Alternatif }\end{array}$ & $\begin{array}{c}\text { Kekuatan } \\
\text { Kayu }\end{array}$ & Serat Kayu & Tekstur & $\begin{array}{c}\text { Berat } \\
\text { Kayu } / k g\end{array}$ \\
\hline A0025 & Sedang & Berwarnah & Halus & 20 \\
\hline A0026 & Sangat Kuat & Sangat Padat & $\begin{array}{l}\text { Sangat } \\
\text { Halus }\end{array}$ & 30 \\
\hline A0027 & Kuat & Padat & Halus & 30 \\
\hline A0028 & Sangat Kuat & Padat & Sedang & 36 \\
\hline A0029 & $\begin{array}{l}\text { Mudah } \\
\text { Patah }\end{array}$ & Beruas Lurus & Halus & 18 \\
\hline
\end{tabular}

Perubahan matrik data awal menjadi data pembobotan, maksudnya semua data awal diubah dalam bentuk nilai bobot. Data pembobotan dapat dilihat pada Tabel 9. Data Pembobotan.

Tabel 9. Data Pembobotan

\begin{tabular}{lllll}
\hline Kode & C01 & C02 & C03 & C04 \\
Alternatif & & & & \\
\hline A0001 & 5 & 5 & 3 & 5 \\
A0002 & 4 & 5 & 2 & 4 \\
A0003 & 3 & 4 & 4 & 5 \\
\hline
\end{tabular}

\begin{tabular}{lllll}
\hline Kode & C01 & C02 & C03 & C04 \\
Alternatif & & & 3 & 5 \\
\hline A0004 & 5 & 4 & 2 & 3 \\
A0005 & 2 & 3 & 3 & 1 \\
A0006 & 3 & 2 & 4 & 5 \\
A0007 & 5 & 4 & 5 & 5 \\
A0008 & 4 & 5 & 4 & 4 \\
A0009 & 3 & 4 & 3 & 3 \\
A0010 & 3 & 4 & 2 & 4 \\
A0011 & 4 & 4 & 3 & 4 \\
A0012 & 4 & 4 & 3 & 3 \\
A0013 & 3 & 3 & 3 & 1 \\
A0014 & 2 & 2 & 3 & 1 \\
A0015 & 2 & 3 & 2 & 2 \\
A0016 & 2 & 3 & 2 & 1 \\
A0017 & 2 & 2 & 4 & 3 \\
A0018 & 3 & 2 & 4 \\
A0019 & 4 & 2 & 4 & 1 \\
A0020 & 4 & 4 & 3 & 3 \\
A0021 & 4 & 4 & 3 & 5 \\
A0022 & 3 & 3 & 4 & 1 \\
A0023 & 4 & 5 & 5 & 5 \\
A0024 & 3 & 2 & 5 & 5 \\
A0025 & 3 & 2 & 5 & 5 \\
A0026 & 5 & 5 & 4 & 5 \\
A0027 & 4 & 4 & 4 \\
A0028 & 5 & 4 & 3 & \\
A0029 & 2 & 3 & 4 & 5 \\
\hline & & & 4 & 5 \\
\hline
\end{tabular}

Perubahan data pembobotan menjadi data ternormalisasi dilakukan dengan rumus pada persamaan (1).

Proses normalisasi kriteria kekuatan kayu (C01):

$$
\begin{aligned}
\mathrm{C} 01 & =\sqrt{5^{2}+4^{2}+3^{2}+5^{2}+\cdots+2^{2}}=19,33908 \\
& \mathrm{~A} 0001 \mathrm{X}_{11}=\frac{x_{11}}{19,33908}=\frac{5}{19,33908}=0,25854 \\
& \cdots \cdots \\
& \quad \cdots . . \\
& \mathrm{A} 0029 \mathrm{X}_{29} 1=\frac{x_{151}}{19,33908}=\frac{2}{19,33908}=0,10342
\end{aligned}
$$

Proses normalisasi kriteria serat kayu (C02):

$$
\begin{aligned}
\mathrm{C} 02 & =\sqrt{5^{2}+5^{2}+4^{2}+4^{2}+\cdots+3^{2}}=19,57039 \\
& \mathrm{~A} 0001 \mathrm{X}_{12}=\frac{x_{12}}{19,57039}=\frac{5}{19,57039}=0,25549 \\
& \cdots \cdots \cdots \\
& \cdots \cdots \cdots . . \\
& \mathrm{A} 0029 \mathrm{X}_{29}{ }_{2}=\frac{x_{152}}{19,57039}=\frac{3}{19,57039}=0,15329
\end{aligned}
$$

Proses normalisasi kriteria tekstur (C03):

$$
\begin{gathered}
\mathrm{C} 03=\sqrt{3^{2}+2^{2}+4^{2}+3^{2}+\cdots+4^{2}}=18,81489 \\
\mathrm{~A} 0001 \mathrm{X}_{13}=\frac{x_{13}}{18,81489}=\frac{3}{18,81489}=0,15945
\end{gathered}
$$




$$
\mathrm{A} 0029 \mathrm{X}_{29} 3=\frac{x_{153}}{18,81489}=\frac{4}{18,81489}=0,2126
$$

Proses normalisasi kriteria berat kayu (C04):

$$
\begin{aligned}
\mathrm{C} 04 & =\sqrt{5^{2}+4^{2}+5^{2}+5^{2}+\cdots+2^{2}}=20,17424 \\
& \mathrm{~A} 0001 \mathrm{X}_{14}=\frac{x_{14}}{20,17424}=\frac{5}{20,17424}=0,24784 \\
& \cdots \cdots . . \\
& \cdots \cdots . . \\
& \mathrm{A} 0029 \mathrm{X}_{29} 4=\frac{x_{154}}{20,17424}=\frac{2}{20,17424}=0,09914
\end{aligned}
$$

Selanjutnya dari perhitungan persamaan (1) menghasilkan sebuah matriks ternormalisasi $r$, yang terlihat pada Tabel 10. Data Normalisasi.

\begin{tabular}{lllll}
\multicolumn{5}{c}{ Tabel 10. Data Normalisasi } \\
\hline Kode & C01 & C02 & C03 & C04 \\
Alternati & & & & \\
f & & & & \\
\hline A0001 & 0,25854 & 0,25549 & 0,15945 & 0,24784 \\
A0002 & 0,20684 & 0,25549 & 0,1063 & 0,19827 \\
A0003 & 0,15513 & 0,20439 & 0,2126 & 0,24784 \\
A0004 & 0,25854 & 0,20439 & 0,15945 & 0,24784 \\
A0005 & 0,10342 & 0,15329 & 0,1063 & 0,1487 \\
A0006 & 0,15513 & 0,1022 & 0,15945 & 0,04957 \\
A0007 & 0,25854 & 0,20439 & 0,2126 & 0,24784 \\
A0008 & 0,20684 & 0,25549 & 0,26575 & 0,24784 \\
A0009 & 0,15513 & 0,20439 & 0,2126 & 0,19827 \\
\hline & & & & \\
Kode & C01 & C02 & C03 & C04 \\
Alternati & & & & \\
f & & & 0,159 & \\
\hline A0010 & 0,15513 & 0,20439 & 0,15945 & 0,1487 \\
A0011 & 0,20684 & 0,20439 & 0,1063 & 0,19827 \\
A0012 & 0,20684 & 0,20439 & 0,15945 & 0,19827 \\
A0013 & 0,15513 & 0,15329 & 0,15945 & 0,1487 \\
A0014 & 0,10342 & 0,1022 & 0,15945 & 0,04957 \\
A0015 & 0,10342 & 0,15329 & 0,15945 & 0,04957 \\
A0016 & 0,10342 & 0,15329 & 0,1063 & 0,09914 \\
A0017 & 0,10342 & 0,1022 & 0,1063 & 0,04957 \\
A0018 & 0,15513 & 0,1022 & 0,2126 & 0,1487 \\
A0019 & 0,20684 & 0,1022 & 0,2126 & 0,04957 \\
A0020 & 0,20684 & 0,20439 & 0,15945 & 0,1487 \\
A0021 & 0,20684 & 0,20439 & 0,15945 & 0,24784 \\
A0022 & 0,15513 & 0,15329 & 0,2126 & 0,04957 \\
A0023 & 0,20684 & 0,25549 & 0,26575 & 0,24784 \\
A0024 & 0,15513 & 0,1022 & 0,2126 & 0,24784 \\
A0025 & 0,15513 & 0,1022 & 0,2126 & 0,1487 \\
A0026 & 0,25854 & 0,25549 & 0,26575 & 0,24784 \\
A0027 & 0,20684 & 0,20439 & 0,2126 & 0,24784 \\
A0028 & 0,25854 & 0,20439 & 0,15945 & 0,24784 \\
A0029 & 0,10342 & 0,15329 & 0,2126 & 0,09914 \\
\hline & & & & \\
\hline
\end{tabular}

Proses selanjutnya yaitu, perangkingan dengan menggunakan bobot yang telah diberikan oleh pengambilan keputusan dalam hal ini berarti sang pakar, yaitu:

$$
\mathrm{W}=\{20,35,30,15\}
$$

untuk menghasilkan nilai akhir dengan menggunakan persamaan (2). Proses perhitungan untuk mendapatkan yaitu:

$$
\begin{aligned}
& \text { A0001 } \\
& \begin{aligned}
\mathrm{Y} 1=\sum & (0.25854 \times 20)+(0.25549 \times 35)+(0.15945 \\
\mathrm{x} 30) & -\sum(0.24784 \times 15) \\
& =18,89645-3,7176 \\
& =15,17885
\end{aligned} \\
&
\end{aligned}
$$

Sehingga dari perhitungan persamaan (2) menghasilkan nilai perangkingan yang terlihat pada Tabel 11. Data Perangkingan.

\begin{tabular}{lllll}
\multicolumn{5}{c}{ Tabel 11. Data Perangkingan } \\
\hline Kode & Kode & Nama Kayu & Hasil & Rank \\
& Alternati & & \\
& f & & \\
\hline Y26 & A0026 & Bubinga & 18,36785 & 1 \\
Y23 & A0023 & Bocote & 17,33385 & 2 \\
Y8 & A0008 & Eboni & 17,33385 & 3 \\
Y1 & A0001 & Kayu Jati & 15,17885 & 4 \\
Y7 & A0007 & Ulin & 14,98485 & 5 \\
Y22 & A0022 & MDF & 14,1022 & 6 \\
Y27 & A0027 & Tigerwood & 13,95085 & 7 \\
Y20 & A0020 & Punak & 13,84345 & 8 \\
Y9 & A0009 & Trembesi & 13,6602 & 9 \\
Y28 & A0028 & Lignum vitae & 13,39035 & 10 \\
Y4 & A0004 & Merbau & 13,39035 & 11 \\
Y19 & A0019 & Gaharu & 13,34825 & 12 \\
Y2 & A0002 & Mahogani & 13,2939 & 13 \\
Y12 & A0012 & Sonokeling & 13,0999 & 14 \\
Y3 & A0003 & Meranti & 12,91665 & 15 \\
Y10 & A0010 & Bangkirai & 12,80925 & 16 \\
Y21 & A0021 & Borneo & 12,35635 & 17 \\
Y29 & A0029 & Mindi & 12,32445 & 18 \\
Y11 & A0011 & Kamper & 11,5054 & 19 \\
Y15 & A0015 & Cemara & 11,4735 & 20 \\
Y13 & A0013 & Sungkai & 11,02075 & 21 \\
Y25 & A0025 & Pink ivory & 10,8271 & 22 \\
Y18 & A0018 & Gelam & 10,8271 & 23 \\
Y6 & A0006 & Cendana & 10,71955 & 24 \\
Y14 & A0014 & Pinus & 9,68535 & 25 \\
Y24 & A0024 & Purple heart & 9,34 & 26 \\
Y16 & A0016 & Kelapa & 9,13545 & 27 \\
Y5 & A0005 & Albasia & 8,39205 & 28 \\
Y17 & A0017 & Aren & 8,09085 & 29 \\
\hline
\end{tabular}

\subsection{Perhitungan Sistem}

Untuk membuktikan perhitungan manual di atas, maka perlu bukti perhitungan dari sistem. 


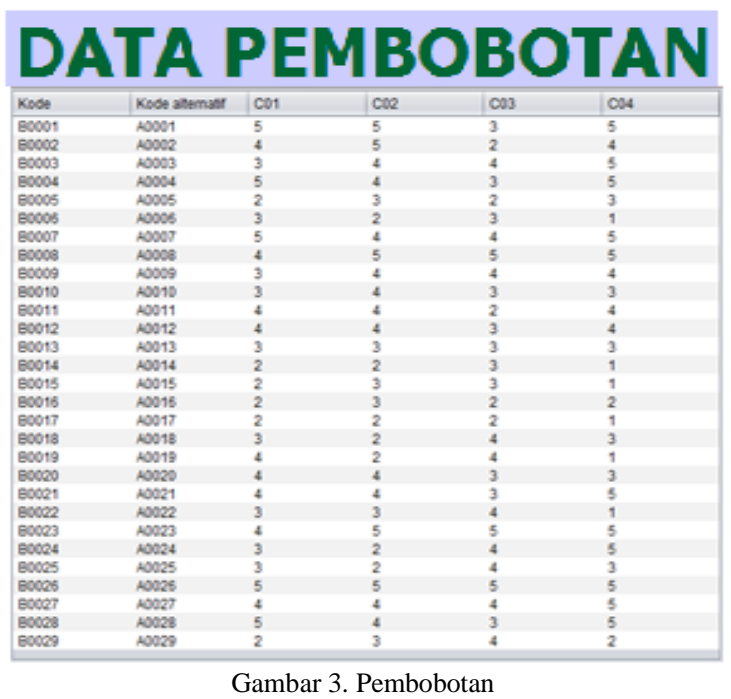

Pada Gambar 3. Pembobotan, berisikan atribut kode untuk inisialisasi kode pembobotan, kode alternatif, C01 adalah inisialisasi dari kriteria kekuatan kayu, $\mathrm{C} 02$ adalah inisialisasi dari kriteria serat kayu, C03 adalah inisialisasi dari kriteria tekstur, dan $\mathrm{C} 04$ adalah inisialisasi dari kriteria berat kayu.

\begin{tabular}{|c|c|c|c|c|c|}
\hline Kode & Kode atematt & $\cos$ & $c 00$ & 003 & $\cos 4$ \\
\hline 100501 & A0509 & 025954 & 025849 & Q.15945 & 0.25784 \\
\hline 100002 & 20000 & 020584 & 0.25649 & 0.1053 & 0.19827 \\
\hline 100003 & .0503 & 0.15513 & 0.20439 & 0.2128 & 0.24784 \\
\hline 100004 & A0504 & 0.25954 & 020439 & $0.15 \% 45$ & 0.24784 \\
\hline 100005 & A0005 & 0.10342 & 0.15329 & 0.1083 & 0.1437 \\
\hline novos & 20005 & 0.15513 & 0.9022 & 0.15345 & 0.04957 \\
\hline 100007 & A0507 & 025854 & 020438 & 0.2126 & 0.24784 \\
\hline NoD0s & 20003 & 020684 & 0.25549 & 0.26575 & 0.24784 \\
\hline 100009 & 10009 & 0.15513 & 020439 & 0.2126 & 0.19627 \\
\hline No010 & 10010 & Q. 15513 & 020439 & Q.15965 & Q.14a7 \\
\hline Noort1 & A0011 & 020584 & 020439 & 0.1053 & Q. 19827 \\
\hline 10012 & 20012 & 0.20824 & 020439 & Q. 15345 & 0.19627 \\
\hline N00013 & 40013 & 0.15513 & 0.15329 & 0.15955 & 0.1487 \\
\hline No014 & 10014 & 0.10342 & 0.1022 & 0.15945 & 0.06957 \\
\hline 100015 & novis & 0.10342 & 0.15329 & 0.15ass & 0.04957 \\
\hline 1000t5 & A0016 & 0.10342 & 0.15328 & Q 1083 & 0.09914 \\
\hline 100017 & $A 0017$ & Q.10342 & 0.1002 & Q.1063 & 0.04557 \\
\hline 10013 & 20018 & 0.15513 & 0.1002 & 0.2125 & 0.1487 \\
\hline 100019 & 40019 & 020684 & 0.1002 & 0.2126 & 0.06357 \\
\hline 100020 & 10020 & 020584 & 0.20439 & 0.15945 & 0.1487 \\
\hline 100021 & 10021 & 020564 & 020439 & Q 15945 & 024784 \\
\hline 100022 & 100022 & 0.15513 & 0.15328 & 0.2126 & 0.04857 \\
\hline 100023 & 20023 & O203es & 025549 & 0.28575 & 0.24784 \\
\hline 100024 & 100024 & 0.15513 & 0.9022 & 0.2126 & 0.24784 \\
\hline Noves & nones & 0.15513 & 0.10022 & 0.2126 & 0.1487 \\
\hline towos & A0025 & 0.25954 & 0.25549 & 0.26575 & 0.24784 \\
\hline 100027 & 20027 & 0.20684 & 020439 & 0.2126 & 0.24784 \\
\hline novoes & 20028 & 0.25854 & 0.20439 & 0.15945 & 024784 \\
\hline nobeg & 10029 & 0.10342 & 0.15329 & 0.2128 & 0.09914 \\
\hline
\end{tabular}

Pada Gambar 4. Normalisasi, berisikan atribut kode untuk inisialisasi kode normalisasi, kode alternatif, C01 adalah inisialisasi dari kriteria kekuatan kayu, C02 adalah inisialisasi dari kriteria serat kayu, C03 adalah inisialisasi dari kriteria tekstur, dan $\mathrm{C} 04$ adalah inisialisasi dari kriteria berat kayu.

\section{LAPORAN PERANGKINGAN}

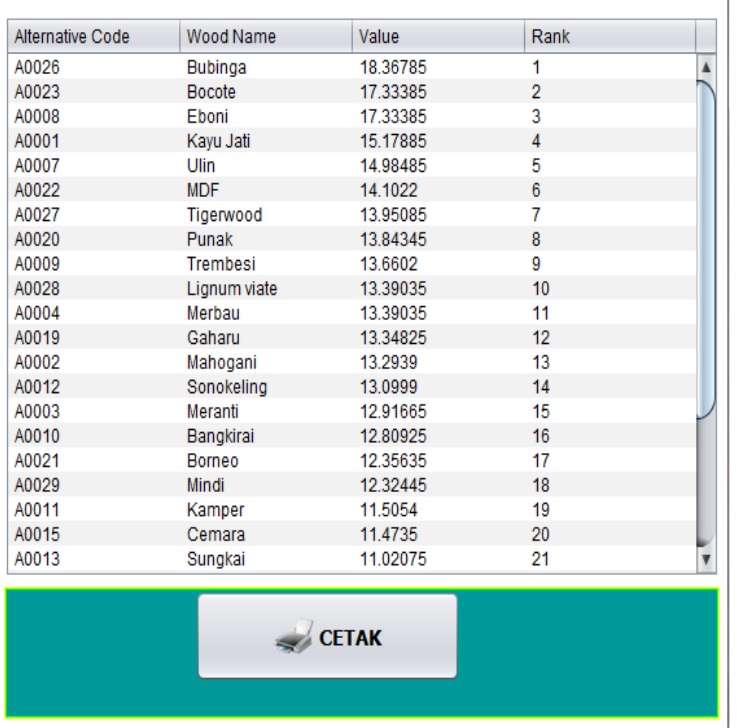

Gambar 5. Perangkingan

Pada Gambar 5. Perangkingan, berisikan atribut kode alternatif, nama kayu, hasil, dan peringkat. Setelah dilakukan pembuktian terhadap perhitungan sistem, baik dari hasil rekomendasi dan nilai sama dengan perhitungan manual, dimana 3 kayu terbaik yang layak direkomendasikan untuk pembuatan bahan gitar adalah kayu Bubinga, Bocote, dan Eboni.

\subsection{Akurasi}

Pada Tabel 11. Data Perangkingan menjelaskan tentang hasil dari perhitungan manual dengan perhitungan dalam sistem kemudian disesuaikan dengan fakta dilapangan apakah telah sesuai atau belum. Hasil yang diperoleh memiliki tingkat akurasi $100 \%$, melalui pengujian rumus tingkat akurasi dari data asli dengan sistem, berikut ini adalah cara penghitungan tingkat akurasi program:

a. Data responden pengrajin kayu $=10$

b. Data hasil sama dengan data original $=17$

c. Data hasil tidak sama dengan data original $=0$

$$
\text { Akurasi }=\frac{N}{\mathrm{~N}+\mathrm{Ni}} \times 100 \%
$$

Dengan nilai $N$ ialah total sesuai, $N i$ ialah total tidak sesuai.

$$
\text { Akurasi sistem }=\frac{17}{17+0} \times 100 \%=100 \%
$$

Data yang dihasilkan dalam penelitian ini sebesar $100 \%$ berdasarkan perhitungan manual dengan sistem dari 29 data kayu yang dipraktikan secara langsung oleh responden pengrajin kayu.

$$
\text { Akurasi pakar }=\frac{13}{13+2} \times 100 \%=86,67 \%
$$


Data yang dihasilkan dalam penelitian ini, menurut pakar pembuat gitar, yaitu dari 15 pakar pembuat gitar, 13 mengatakan setuju dengan peringkat 3 terbesar, dan 2 mengatakan kurang setuju. Sehingga ditemukan tingkat akurasi berdasarkan penilaian pakar sebesar $86,67 \%$.

\section{KESIMPULAN}

Setelah dilakukan penelitian dan implementasi dalam penentuan kayu terbaik dengan menggunakan metode MOORA, menghasilkan kesimpulan bahwa 3 kayu terbaik yang layak untuk digunakan dalam pembuatan gitar secara berurutan dalah kayu Bubinga dengan nilai 18,36785, kayu Bocote dengan nilai 17,33385, dan kayu Eboni dengan nilai 17,33385 dari beberapa pilihan alternatif kayu yang ada. Membuktikan hasil dari metode MOORA, maka dilakukan responden secara langsung dengan memberikan hasil metode kepada pakar pembuat gitar. Dari 15 pakar pembuat gitar, 13 mengatakan setuju dengan peringkat 3 terbesar, dan 2 mengatakan kurang setuju. Sehingga ditemukan tingkat akurasi berdasarkan penilaian pakar sebesar $86,67 \%$.

\section{DAFTAR PUSTAKA}

CAHYANI, L., ARIF, M. \& NINGSIH, F. 2019. Sistem Pendukung Keputusan Pemilihan Mahasiswa Berprestasi Menggunakan Metode Moora ( Studi Kasus Fakultas Ilmu Pendidikan Universitas Trunojoyo Madura. Jurnal Ilmiah Edutic, 5(2), pp. 108-114.

CHAKRABORTY, S. \& ZAVADSKAS, E. K. 2014. Applications of WASPAS method in manufacturing decision making. Informatica (Netherlands). 25(1), pp. 1-20. doi: 10.15388/Informatica.2014.01.

KAUTSAR, A. F. AL 2016. Mahir Bermain Gitar. Yogyakarta: Genesis Learning.

MAHARANI, S, dkk. 2018. Pemilihan Taman Kanak-kanak Menggunakan Metode Weighted Product di Kecamatan Sungai Kunjang Samarinda. Jurnal Teknologi Informasi dan Ilmu Komputer(JTIIK), 5(4). doi: 10.25126/jtiik.201854814.

MANURUNG, S. 2018. Sistem Pendukung Keputusan Pemilihan Guru Dan Pegawai Terbaik Menggunakan Metode Moora', Jurnal SIMETRIS, 9(1), pp. 701-706.

NABABAN, L. $d k k$. 2018. Sistem Pendukung Keputusan Penentuan Kelayakan', Jurnal Teknik Informatika Kaputama(JTIK), 2(2), pp. 20-27.

NUGRAHA, H. 2016. Sistem Pendukung Keputusan Pemilihan Kayu Untuk Gitar Menggunakan Metode Technique for Order Preference By Similarity To Ideal Solution (Topsis)', Jurnal
Riset Komputer, 12(1), pp. 334-338.

OLIVIANITA, L. \& EKOJONO. 2016. Sistem pendukung keputusan kelayakan hasil cetakan buku menggunakan metode moora', Seminar Informatika Aplikatif Polinema, 1(9).

PRASETYANINGRUM, P. T., dkk. 2020. Penerapan Simple Additive Weigthing Pemilihian Kayu. 05(01), pp. 1-12.

RAMADANI, A., SIHOMBING, T. R. R. and PARLINA, I. 2019. Sistem Pendukung Keputusan Pemilihan Asuransi Jiwa Pada PT Bhinneka Life Indonesia Pematangsiantar Dengan Menggunakan Metode Moora', (Journal of Informatics and Telecommunication Engineering), 2(2), pp. 62-68.

RANI, F. P, dkk. 2019. Berprestasi Menggunakan Metode Multi Objective Optimization On The Basis Of Ratio Analysis Decision Support System To Select Pandega Scout Achievement Using Multi Objective Optimization On The Basis Of', Jurnal Teknologi Informasi dan Ilти Koтputer (JTIIK), 6(2), pp. 155-162. doi: 10.25126/jtiik.201961284.

SIMANJUNTAK, P, dkk. 2018. Penentuan Kayu Terbaik Untuk Bahan Gitar Dengan Metode Weighted Aggregated Sum Product Assessment ( WASPAS )', Jurnal Riset Komputer (Jurikom), 5(1), pp. 36-42.

ZIAN, FAHRI, 2014. Rahasia Jago Gitar Otodidak Tanpa Guru:Khusus Untuk Pemula. Jakarta: Lembar Pustaka Indonesia. 
Halaman ini sengaja dikosongkan 